\title{
肝硬変患者に拈ける血漿 endothelin-1上昇の機序について
}

$\begin{array}{rrrrrr}\text { 櫻林 } & \text { 鼻 } & \text { 平野 } & \text { 正憲 } & \text { 山本 } & \text { 佳洋 } \\ \text { 鈴木 } & \text { 剛 } & \text { 西村 } & \text { 秀司 } & \text { 安部 } & \text { 潔 } \\ \text { 吉野 } & \text { 克正 } & \text { 岩瀬 } & \text { 透 } & \text { 岡 } & \text { 博* }\end{array}$

粕言：1988年，柳沢ら”により血管内皮より強力な 血管収縮ペプチドである endothelin が単離され，その 後の研究により肝硬変における血漿 endothelin-

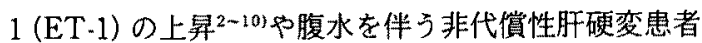
での高值 $25,7,8,811)$ などが報告された。しかし，肝硬変に おけるET-1上昇の機序は未だ明確でない。そこで今 回われわれは経皮経肝門脈造影時に門脈血槳中の ET-1濃度を湘定し，訮硬変患者におけるET-1の全身 動態ならびにET-1上昇の機序について検討した。

対象および方法：対象は肝硬変21例（男13例，女 8 例, 平均年龄61葴), コントロールとして4 例(男 3 例, 女 1 例, 平均年齢66歳)である. 肝硬変の原因は $\mathrm{HBV}$ 2 例, HCV 10例, alcohol 6 例, 自己免疫性肝炎 1 例, 不明 2 例であった. Child 分類ではそれぞれA 8 例, B 8 例, C 5 例であった.また,コントロール症例はア ルコール性肝障害, 無症候性原発性胆汁性肝硬変 ( $\mathrm{aPBC}$ ), 胃癌, 膵癌が各 1 例であった.

全症例において早朝安静空腹時に静脈血槳 ET-1濃 度を測定した。このうち12例(肝硬変10例, Child A 6, B 4, コントロール 2 例, $\mathrm{aPBC}$ およびアルコール性肝 障害各 1 例) では経皮経肝門脈造影を施行し，その際 門脈本幹, 肝静脈, 上腸間膜静脈, 脾静脈および動脈 より採血し，血漿 ET-1濃度を同時測定した.さらに肝 および末梢でのET-1除去率を(門脈血濃度一肝静脈 血濃度 $) /$ 門脈血濃度 $\times 100(\%)$ ，(動脈血濃度一静脈血 濃度) / 動脈血濃度 $\times 100$ (\%) として求めた。血槳 ET. 1 濃度は採血後 $3 \mathrm{~m} l$ を直ちに血策分離し, $-20^{\circ} \mathrm{C} て ゙$ 凍 結保存後, ET-1娜定用試薬 (和光純薬) にて EIA 法に より測定した ${ }^{122}$ ．統計学的検討は Mann-Whitney Utestにて行った.

結果：1. 各部位での血獎 ET-1濃度

肝硬変群, コントロール群とも血獎 ET-1濃度は門 脈, 上腸間膜静脈にて最も高值であった。静脈血漿

\footnotetext{
*東京警察病院消化器センター内科
}

く受付日1996年7月1日〉
ET-1濃度は肝硬変群にて2.44 $\pm 0.19 \mathrm{pg} / \mathrm{m} l$ （mean士 $\mathrm{SE})$ であり, コントロール群 $(1.29 \pm 0.22 \mathrm{pg} / \mathrm{ml})$ と 比較して有意に高値であった $(\mathrm{p}<0.05)$. 動脈, 門脈, 肝静脈, 上腸間膜静脈, 脾赩脈血獎 ET-1濃度の比較で は肝硬変群にて動脈, 肝静脈, 脾静脈で高値を示した (図 1).

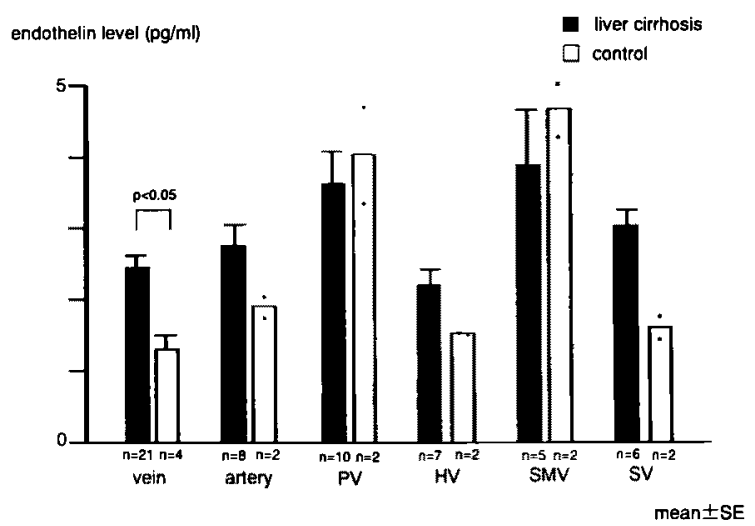

图 1 各部位での血槳 ET-1濃度 PV : 門脈, $\mathrm{IIV}$ : 肝静脈, SMI : 上腸間膜静脈, SV : 脾静脈
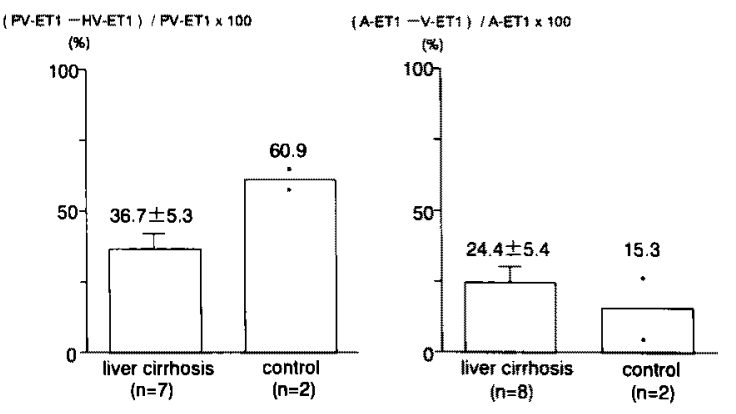

図2肝および末梢ET-1除去率

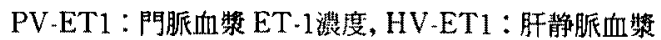
ET-1濃度, A-ET1：動脈血獎ET-1澧度, V-ET1：静 脈血脂 ET-1濃度 
2. 肝および末梢 ET-1除去率

肝での ET-1除去率は肝硬変群 $36.7 \pm 5.3 \%$, コント ロール群60.9\% $(67.6,54.2)$ と肝硬変群で低下を示 した。末梢でのET-1除去率注肝硬変群 $24.4 \pm 5.4 \%$, コントロール群 $15.3 \%(26.1 ， 4.5)$ であった（図 2$)$.

考察：肝硬変に拈ける血墏中 ET-1の上昇の機序は 明らかではない. Uchihara らは肝硬変㭧者において， endotoxin 血症患者で有意に ET-1が上昇していたこ とより, endotoxin が ET-1合成を刺激しているのでは ないかと推測し2), Moore らは肝腎症候群において, ET-1の高值を認め，同疾患にて腎でのクリアランスが ないことを示しだ!。後, Gerbesらは肝硬変患者 において, 肝静脈血墏 ET-1濃度が動脈血より高值で あったことより，肝硬変におけるET-1上昇は splanchnic 由来である可能性を示唆した ${ }^{109}$. 今回のわれわ れの検討で注肝硬変患者, コントロール患者とも門脈 本幹, 上晹間膜静脈血漿 ET-1が循環血墏中で最も高 值であった。これは ET-1枕よびET-30合成が rat の 回腸, 大腸で認められたという報告 ${ }^{13)}$ と一致する。以上 より，ET-1の主な産生部位は腸管であることが確認さ れた。さらに、肝でのET・1除去率が肝硬変群で低下し ていたことょり，肝硬変症において静脈血漿 ET-1濃 度が上昇すると説明しうる，なお，四塩化炭素による
肝線維化 ratに扔いては訮灌流法により ET-1投与後, 肝通過後の灌流液 ET-1がコントロールと比較して高 值であり, 肝でのET-1除去の低下の原因はET-1の異 化の低下と推測されている ${ }^{147}$.肝でのET-1異化の低下 の要因としては insulinやアンモニアと同様に肝内 シャントと肝実質機能低下の両者が関与していると考 えるのが妥当と思われる。

索引用語：肝硬変, endothelin-1, 肝除去 文 献：1）Yanagisawa $M$, et al： Nature $332: 411$ $-415,1988$ 2) Uchihara $M$, et al: Hepatology $16: 95-99,1992$ 3) Moore $k$, et al: N Eng J Med $327: 1774-1778,1992$ 4) Uchida Y, et al : Gastroenterol Jpn $28: 666-672,1993$ 5) Asbert $M$, et al : Gastroenterology 104 : 1485-1491, 1993 6) Moller S, et al: J Hepatol 19:285-290, 1993 7) Matsumoto H : Dig Dis Sci 39: 2665-2670, 1994 8) Salo J, et al: J Hepatol 22: 389-398, 1995 9) Tsai YT, et al: J Hepatol 23:681-688, 1995 10) Gerbes A, et al: Hepatology 21: 735-739, 1995 11) Bernardi M, et al: J Hepatol 24: 161-168, 1996 12) Suzuki $N$, et al: J Immunol Methods 118: $245-250,1989$ 13) Takahashi $K$, et al : Gastroenterolgy 99：1660-1667, 1990 14) 内田 靖：肝臟 $34: 328-334,1993$ 